\title{
Mobile Apps for Boarding House Recommendation
}

\author{
https://doi.org/10.3991/ijim.v14i11.11574 \\ Faried Effendy ${ }^{(凶)}$, Kartono, Dyah Herawatie \\ Universitas Airlangga, Surabaya, Indonesia \\ faried-edfst.unair.ac.id
}

\begin{abstract}
This research aims to build a boarding house recommender system based on the Fuzzy TOPSIS method. This application can be utilized by the student community to discover a suitable boarding house. This research uses the classic life cycle (waterfall) as a software development model. The waterfall model consists of 5 stages, namely, communication, planning, modeling, construction, and deployment. In this study, we focus on the construction and deployment stage.

To test and assess the system, we use a questionnaire filled by the respondents. Two arrangements of surveys created, one for the students and another for mobile application experts. We use ISO 9126 as a base to assess the system in terms of functionality, usability, content, reliability, and performance. As a result, these mobile apps graded 3.54 and categorized as an excellent system. This system is well-honorable and acknowledged by the student community, which gives a superior, simple method for promoting and reliable tool for finding appropriate boarding houses. The users recommend adding some features such as boarding communities, ratings, reviews so users can communicate with each other and increase the effectiveness and functionality of the application.
\end{abstract}

Keywords - Boarding house, recommendation, mobile application, fuzzy TOPSIS

\section{Introduction}

Surabaya is one of Indonesia's metropolitan cities where more than 70 universities, polytechnics, institutes, academies, and colleges are located. Although some campuses provide dormitories, due to limited space, most out-of-towns students have to find another place of residence in the form of rent. Most out-of-towns students rent or live in boarding houses in Surabaya to save time and money, and this has resulted in an increasing number of boarding houses in Surabaya. The boarding house is an impermanent house lease by a settled outsider or somebody who remains a route from home. Currently, there are hundreds of boarding houses in Surabaya with various facilities and diverse rental prices.

Accommodation has been a significant issue for students that live out of their town or their country[1]. One of the academic successes came from a place that safe, comfortable, and proximity to the university. In contrast, discomfort accommodation can cause stress, physical, and psychological difficulties, also misery [2]. To search for a 
suitable boarding house is not easy, limited information, relationships, mobility, and time was the main problems [2]-[6]. The complexity of boarding searches is mainly due to several interrelated factors, including facility, price, reference, location, service, security, reputation, and advertising. For example, the rental price will be affected by the distance of the boarding house from the campus, facilities, and services provided at the boarding house. Although there are many boarding house recommender applications, most of them only display images, prices, and other facilities described by the owner.

The popularity of smart mobile devices is growing fast [7]. A key reason for the popularity of smart mobile devices is related to the technological features of these devices. Large screen displays, high resolution, lightweight, user-friendly and ergonomic design, short start-up time, multimedia content viewing ability, are just to name a few [8]-[10]. Mobile touchscreen technologies, also referred to as tablet technologies, are revolutionizing the interactive digital experiences of young age people. Ideally, smart devices accompanying applications (apps) can create exciting and effective environments for learning and entertainment.

Previous studies on the recommendation system have been carried out with various techniques such as collaborative screening [11]-[13], personal preferences [14]-[16], or the combination. Each of them has their background and strengths. Many studies address the problem of boarding searches [5], [17], [18], [19], but not much discussed the user preferences. Planning a system that can help in determining the boarding house is needed by students in finding housing that fits the desired criteria. In this study, we develop an Android Application for recommendation systems based on Fuzzy TOPSIS and Geographic Information Systems (GIS). The recommendation system combined with GIS so that the information obtained is not only textual but also in the form of spatial or interactive maps. This app will provide recommendations about the existence and location of boarding houses, fares, facilities owned, and other related information based on criteria chosen by the user.

\section{Background}

This research relies on the Waterfall method, Boarding house concepts and selection factors, Fuzzy TOPSIS, and Software quality base on ISO 9126. The schematic diagram of this research is shown in Figure 1.

\subsection{Waterfall method}

Waterfall Model is a classic approach in software development that illustrates linear and sequential development methods. This method consists of five phases, each phase defined by different tasks and objectives, where the whole phase describes the software life cycle until its delivery. After the phase is complete, the next development step follows, and the results from the previous phase flow to the next phase [20].

There are five stages in the Waterfall Model [20], namely: 
Communication: This stage is an analysis of system requirements that can be done through research, interviews, or study literature. This stage will produce a user requirements document.

Planning: The next stage is the planning stage which explains the estimated technical tasks to be performed, the risks that can occur, the resources needed to make the system, the work products to be produced, the scheduling of work to be carried out, and the tracking of the process of working the system.

Modeling: This stage is to design and to model the system architecture that focuses on designing data structures, software architectures, display interfaces, and program algorithms. The aim is to get the big picture of the system.

Construction: The implementation phase is followed by the testing of all software components, modules, and the entire system. Integration into specific operating systems is also examined. If errors and conflicts occur, they must be corrected immediately. This can lead to an increase in overall costs due to errors that might be related to different phases and not always due to the previous phase.

Deployment: After conducting a series of testing and development, the application program is ready to be distributed to users. Users are asked for feedback to be a developer evaluation. At this stage, it is also possible to add features or functions that are not yet available in the program based on user feedback.

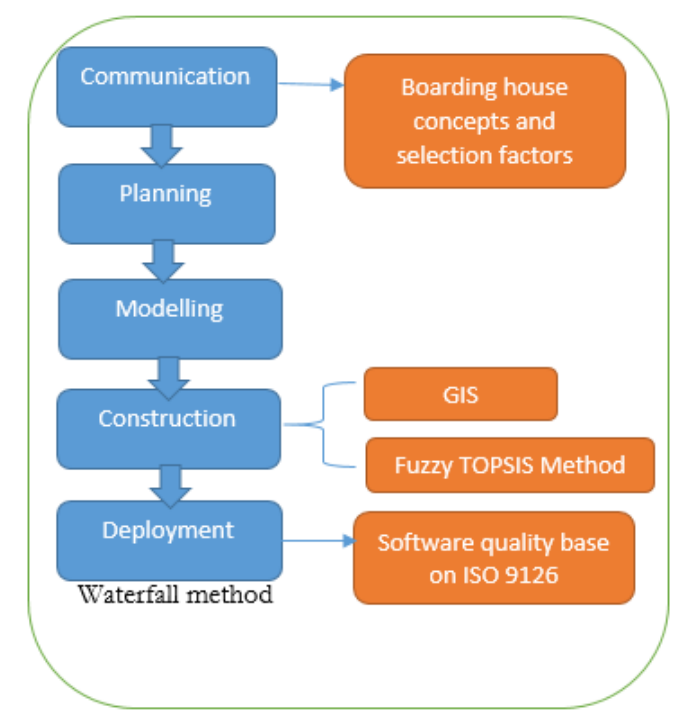

Fig. 1. The schematic diagram

\subsection{Boarding house concepts and selection factors}

A boarding house is a service that offers a room or place to live in with a certain amount of payment for each particular period (generally monthly payments). This word is absorbed from the Dutch phrase "in de kost." The definition of "in de kost" is actually 
"eating inside," but it can also mean "stay and eat" in the house where you live [21]. Boarding houses have many names, such as temporary housing [22], halls of residence, student housing [23], and university accommodation [24].

Many studies discussed the factors that influence student's decisions in choosing a boarding house, including [25], which states that boarding house selection influenced by the facility, price, reference, location, service, security, and reputation factors. While [26] states that boarding house selection influenced by two factors, namely, internal and external factors. Internal factors are factors that are affected by tenant characteristics, while external factors influenced by physical, accessibility, environment, facilities. In another study [3], it was said that location, advertising, facilities, and price factors were the determining factors in choosing a boarding house.

Based on the results of studies, consumers have different preferences in choosing a boarding house. So in this study, we combined the factors obtained from the results of a survey of 200 students who sought boarding with the factors obtained in previous studies.

\subsection{Fuzzy TOPSIS method}

Fuzzy Technique for Order Preference method by Similarity to Ideal Solution (FTOPSIS) is one method of many problem-solving in MCDM (Multi-Criteria Decision Making) Decision Support Systems. In this method, various criteria considered in a relatively difficult computerized decision-making process. The Fuzzy method has been proven effective in mathematically solving a variety of linguistic problems since Dr. Lotfi Zadeh first introduced it in 1965. Meanwhile, TOPSIS is a classic method that has been used by Hwang and Yoon since the beginning of the MCDM problem. In the TOPSIS method, we need criteria and appropriate data ranking. However, the available data is generally not fulfilled because of the human judgment factor that cannot be changed to be a fixed number (numeric). Therefore, to overcome the vagueness of human thought or vague assessment factors, Dr. Lotfi Zadeh introduces the fuzzy set theory. Fuzzy logic is a mathematical logic that has been proven effective and easy in modeling solutions such as systems that are not clear, such as in industry, nature, or humans, or linguistic factors, and use as a facilitator of reasoning for decision making that is not accompanied by complete information and accurate.

Fuzzy Number is a fuzzy subset of real numbers and symbolizes the development of the concept of a confidence interval. One of them is the triangular fuzzy number (TFN). The TFN membership function presented in Figure 2.7 and $A=(\mathrm{a}, \mathrm{b}, \mathrm{c})$, which is described by the equation [27]:

$$
\mu A(x)=\left\{\begin{array}{l}
\frac{x-a}{b-a} \text { for } a \leq x \leq b \\
\frac{c-x}{c-b} \text { for } b \leq x \leq c \\
O, \text { otherwise }
\end{array}\right.
$$

Fuzzy TOPSIS method focuses on ranking and choosing from a set of samples with different criteria, which can help decision-makers to get final decisions [28]. This 
method is advantageous in situations where decision-makers cannot make choices during the initial design of a system. There are five steps in determining compromise ranking using the Fuzzy TOPSIS method. The ranking steps are as follows:

1. Build an evaluation matrix $\tilde{x}_{i j}=\left(l_{i j}, m_{i j}, u_{i j}\right)$ with:

$$
l_{i j}=\min \left\{l_{i j}^{k}\right\}, m_{i j}=\frac{1}{K} \sum_{k=1}^{K} m_{i j}^{k}, u_{i j}=\max \left\{u_{i j}^{k}\right\}
$$

$m=$ number of alternative,

$n=$ number of criteria,

$k=$ number of decision makers

So we get $\left(\tilde{x}_{i j}\right)_{m \times n}$ matrix

2. Normalized $\left(\tilde{x}_{i j}\right)_{m \times n}$ matrix to form $\tilde{R}$, with

$$
\begin{aligned}
& \qquad \tilde{R}=\left[\tilde{r}_{i j}\right], i=1,2, \ldots, m, j=1,2, \ldots, n, \\
& \left\{\begin{array}{l}
\tilde{r} i j=\left(\frac{l_{i j}}{u_{j}^{+}}, \frac{m_{i j}}{u_{j}^{+}}, \frac{u_{i j}}{u_{j}^{+}}\right), j \in B, u_{j}^{+}=\max _{i} u_{i j} \text { for } j \in B \\
\tilde{r} i j=\left(\frac{l_{j}^{-}}{u_{i j}}, \frac{l_{j}^{-}}{m_{i j}}, \frac{l_{j}^{-}}{l_{i j}}\right), j \in C, l_{j}^{-}=\min _{i} u_{i j} \text { for } j \in C
\end{array}\right. \\
& \tilde{r}_{i j}=\text { normalization value of each alternative (i) against criterion }(\mathrm{j}) \\
& \mathrm{i}=1,2,3, \ldots . ., \mathrm{m} \text { and } \mathrm{j}=1,2,3, \ldots \ldots ., \mathrm{n} \\
& \mathrm{B}=\text { benefit criteria } \\
& \mathrm{C}=\text { cost criteria }
\end{aligned}
$$

3. Make a weighted normalized decision matrix.

After calculating the normalized value, the next step is to calculate the weighted normalization value by multiplying the value of each alternative of the normalized matrix with the weight given by the decision-maker. The equation below:

$$
\widetilde{V_{l \jmath}}=\widetilde{W}_{j} \times \widetilde{X_{l \jmath}}
$$

$\mathrm{Xij}=$ weighted normalized value

Wij = weight of each criterion

$\mathrm{Vij}=$ normalized value of each alternative

4. Determine fuzzy positive ideal solutions (FPIS) $\boldsymbol{A}^{+}$, and fuzzy negative ideal solutions (FNIS) $\boldsymbol{A}^{-}$.

$$
\begin{aligned}
& A^{+}=\tilde{v}_{1}^{+}, \tilde{v}_{2}^{+}, \ldots, \tilde{v}_{n}^{+} \\
& A^{-}=\tilde{v}_{1}^{-}, \tilde{v}_{2}^{-}, \ldots, \tilde{v}_{n}^{-}
\end{aligned}
$$

5. Calculate the distance between the value of each matrix to FPIS and FNIS. 


$$
\begin{aligned}
& d_{i}^{+}=\sum_{j=1}^{n} d\left(\tilde{v}_{i j}-\tilde{v}_{j}^{+}\right) \\
& d_{i}^{-}=\sum_{j=1}^{n} d\left(\tilde{v}_{i j}-\tilde{v}_{j}^{-}\right)
\end{aligned}
$$

Where $d\left(\tilde{v}_{a}, \tilde{v}_{b}\right)$ is a notation of the distance between the two fuzzy numbers.

6. Calculate the relative proximity or similarity with an ideal solution, with the equation:

$$
S_{i}=\frac{d_{i}^{-}}{d_{i}^{-}+d_{i}^{+}}, i=1,2, \ldots, m .
$$

7. Rank the alternatives sequentially from the largest (best) value based on $S_{i}$ ( $\mathrm{i}=1,2$, ..., m).

\subsection{Software quality based on ISO 9126}

Software quality can be assessed through specific measures and methods, as well as through software testing. One of the software quality benchmarks is ISO 9126, made by the International Organization for Standardization (ISO) and the International Electrotechnical Commission (IEC). ISO 9126 is an internationally recognized standard for quality software. It defines the quality of software products, models, quality characteristics, and related metrics used to evaluate and determine the quality of a software product. If the management does not meet ISO standards, their work cannot be given an ISO standard certificate. The quality factor, according to ISO 9126, includes the following six quality characteristics [29][30]:

a) Functionality: The ability of the software to provide functions according to user needs and satisfy the user.

b) Reliability: The ability of the software to maintain a certain level of performance of the software (ex: accuracy, consistency, simplicity, fault tolerance).

c) Usability: The ability of the software to be studied, used, understood, and attractive to users.

d) Efficiency: The ability of the software to provide appropriate performance and relative to the number of resources used at the time of the situation (ex: storage efficiency).

e) Maintainability: The ability of the software to be modified. Modifications include correction, improvement, or adaptation to environmental changes, requirements, and functional specifications (ex: consistency).

f) Portability: The ability of the software to be transferred from one environment to another or the ability of the software to adapt when used in certain areas (ex: self-documentation, regularly).

In this research, we use part of ISO 9126 to evaluate the system in terms of functionality, usability, content, reliability, and performance. 


\section{Implementation of the System}

\subsection{Communication}

In the first stage of the waterfall, we do research and survey to produce a user requirements document. We conduct an online survey related to the factors that influence in choosing a boarding house. These factors then combined with the factors obtained from the literature studies. The results of the combination of selection criteria are then verified by 100 students who are currently living in the boarding house or student that were still looking for a boarding house. This verification is used to check the results of the criteria with user needs. We also conduct interviews related to the determination of importance weights to provide recommendations to lay users. The expert assesses the importance weights of each of the criteria obtained in the previous step. This interview conducted in the form of a questionnaire. Table 1 showed fifteen criteria and their type obtained from research [2], [21], and surveys conducted on 100 students in Surabaya.

Table 1. Criteria and its type

\begin{tabular}{|l|l|l|l|l|}
\hline \multicolumn{1}{|c|}{ Factor } & Criteria & \multicolumn{1}{|c|}{ Variable } & \multicolumn{1}{c|}{ Type } & \multicolumn{1}{c|}{ Attribute } \\
\hline Security & C1 & CCTV & Linguistic & Benefits \\
\hline Price & C2 & Monthly Boarding Prices & Crisp & Cost \\
\hline & C3 & Payment term system & Linguistic & Cost \\
\hline Location & C4 & Boarding houses distance to campus & Crisp & Cost \\
\hline & C5 & Distance to public facilities & Crisp & Cost \\
\hline Facilities & C6 & Cleaning facilities & Linguistic & Benefits \\
\hline & C7 & Parking facilities & Linguistic & Benefits \\
\hline & C8 & Electronic facilities & Linguistic & Benefits \\
\hline & C9 & Equipment facilities (bed, desk, and chair) & Linguistic & Benefits \\
\hline & C10 & Communal room facilities & Linguistic & Benefits \\
\hline & C11 & Roommate & Crisp & Cost \\
\hline Environment & C12 & The environment around the boarding house & Linguistic & Cost \\
\hline Reputation & C13 & The reputation of a boarding house & Linguistic & Cost \\
\hline Pelayanan & C14 & Clean water service & Linguistic & Benefits \\
\hline & C15 & Electricity service & Linguistic & Benefits \\
\hline
\end{tabular}

\subsection{Planning}

The next stage of the waterfall is planning software development. We make a tight schedule and targets to deliver the apps within six months. We use the Gantt chart as project time management, so we can organize the progress of the project or activity that is being done. 


\subsection{Modeling}

In the third stage, we design and model the system architecture. We set the criteria that have values in the form of exact numbers, such as Monthly Boarding Prices, Boarding houses distance to campus/college, Distance to public facilities, Roommate, are not used fuzzy linguistic variables but crisp numbers. The purpose of using crisp numbers is to facilitate an alternative assessment that will be carried out by experts. The expert does not need to repeat the alternative valuation of the boarding house on certain criteria which have a value in the form of exact numbers. Variables of crisp then changed to TFN (Triangular Fuzzy Number) form.

\subsection{Construction}

In this stage, we develop the mobile application based on user requirements and system architecture model. We use Fuzzy TOPSIS as a ranking method and GIS to visualize the place and the distance. The mobile apps and its Fuzzy TOPSIS calculation described below.

Because this system uses 15 criteria, so it has many possible criteria and sequences that users can choose. For calculation purpose, this study will simulate the apps with the following rules: Monthly Boarding Prices (C2), Boarding houses distance to campus/college (C4), Equipment facilities (bed, desk, and chair) (C9) with priority selection: $\mathrm{C} 2, \mathrm{C} 9, \mathrm{C} 4$. In the main page of the application, users are required to write the campus name as a starting marker, and then the filter page will display the criteria that can be select along with the order of priority.
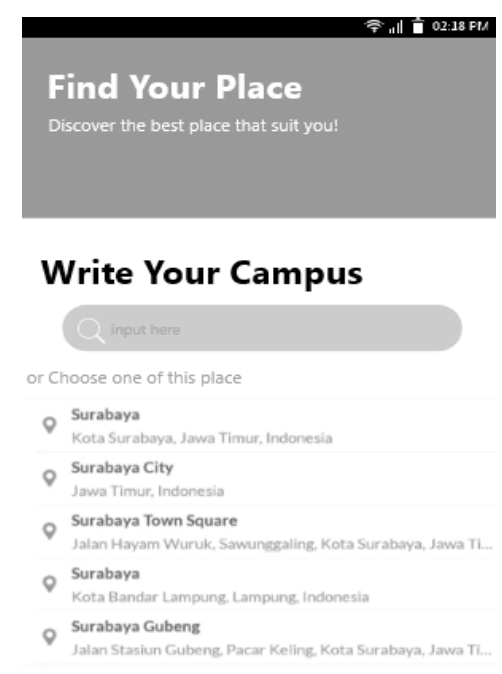

Fig. 2. Main page 


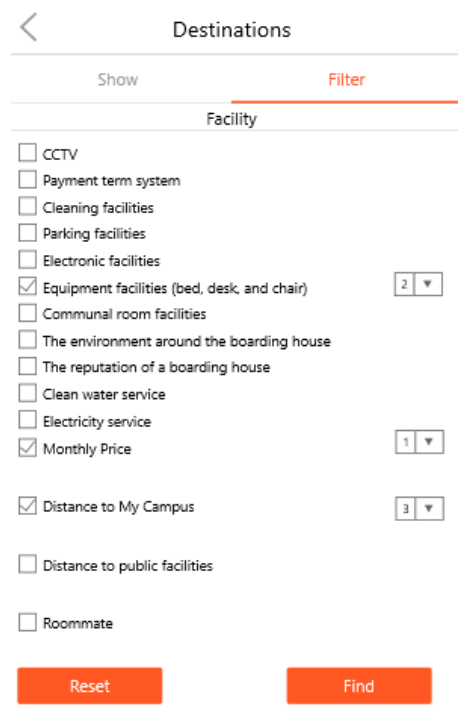

Fig. 3. Filter page

The boarding search generates ten alternative locations, namely Alt- 1 to Alt-10, that can be seen in Table 2 .

Table 2. Alternative data

\begin{tabular}{|l|c|c|c|}
\hline \multicolumn{1}{|c|}{ Alternative } & C2 & C4 & C9 \\
\hline Alt-1 & $1,300,000$ & 2.20 & Yes \\
\hline Alt-2 & $1,500,000$ & 0.45 & No \\
\hline Alt-3 & 450,000 & 3.00 & Yes \\
\hline Alt-4 & 500,000 & 7.10 & No \\
\hline Alt-5 & 800,000 & 3.80 & Yes \\
\hline Alt-6 & $1,200,000$ & 8.80 & No \\
\hline Alt-7 & 400,000 & 0.85 & Yes \\
\hline Alt-8 & $2,250,000$ & 8.90 & Yes \\
\hline Alt-9 & $1,000,000$ & 10.10 & No \\
\hline Alt-10 & $1,500,000$ & 2.00 & No \\
\hline
\end{tabular}

This data normalized by formula (1) and then multiplied by their respective weights to produce a weighted normalized decision matrix, as can be seen in Table 3. Next, FPIS and FNIS values are calculated using formulas (3) and (4) and then calculate the distance between each matrix value with FPIS and FNIS using formula (5), as seen in Table 4. 
Table 3. Weighted normalized decision matrix

\begin{tabular}{|l|c|c|c|c|c|c|c|c|c|}
\hline \multirow{2}{*}{ Alternative } & \multicolumn{3}{|c|}{ C2 } & \multicolumn{3}{c|}{ C4 } & \multicolumn{3}{c|}{ C2 } \\
\cline { 2 - 11 } & \multicolumn{3}{|c|}{$\boldsymbol{~}$ 2 } & \multicolumn{3}{c|}{$\boldsymbol{c}$} & \multicolumn{3}{c|}{} \\
\hline Alt-1 & 0.075 & 0.164 & 0.619 & 0.004 & 0.7 & 105 & 0.7 & 0.9 & 1 \\
\hline Alt-2 & 0.075 & 0.164 & 0.619 & 0.004 & 0.7 & 105 & 0 & 0 & 0 \\
\hline Alt-3 & 0.112 & 0.3 & 1.177 & 0.002 & 0.005 & 1.212 & 0.7 & 0.9 & 1 \\
\hline Alt-4 & 0.112 & 0.3 & 1.177 & 0.002 & 0.002 & 0.618 & 0 & 0 & 0 \\
\hline Alt-5 & 0.075 & 0.164 & 0.619 & 0.002 & 0.005 & 1.212 & 0.7 & 0.9 & 1 \\
\hline Alt-6 & 0.075 & 0.164 & 0.619 & 0.002 & 0.002 & 0.618 & 0 & 0 & 0 \\
\hline Alt-7 & 0.191 & 1 & 4.723 & 0.004 & 0.7 & 105 & 0.7 & 0.9 & 1 \\
\hline Alt-8 & 0.075 & 0.164 & 0.619 & 0.002 & 0.002 & 0.618 & 0.7 & 0.9 & 1 \\
\hline Alt-9 & 0.075 & 0.164 & 0.619 & 0.002 & 0.002 & 0.618 & 0 & 0 & 0 \\
\hline Alt-10 & 0.075 & 0.164 & 0.619 & 0.004 & 0.7 & 105 & 0 & 0 & 0 \\
\hline
\end{tabular}

Table 4. Distance between each matrix value with FPIS and FNIS

\begin{tabular}{|l|c|c|}
\hline \multicolumn{1}{|c|}{ Alt } & di+ & di- \\
\hline Alt-1 & 0.661 & 1.532 \\
\hline Alt-2 & 1.661 & 1.532 \\
\hline Alt-3 & 0.781 & 1.216 \\
\hline Alt-4 & 1.947 & 1.212 \\
\hline Alt-5 & 1.027 & 1.004 \\
\hline Alt-6 & 2.193 & 1 \\
\hline Alt-7 & 0 & 2.193 \\
\hline Alt-8 & 1.193 & 1 \\
\hline Alt-9 & 2.193 & 1 \\
\hline Alt-10 & 1.661 & 1.532 \\
\hline
\end{tabular}

Relative proximity is calculated using the formula (5), for example, to calculate the value of relative proximity A1 as follows:

$$
S_{1}=\frac{d_{1}^{-}}{d_{1}^{-}+d_{1}^{+}}=\frac{1.532}{1.532+0.661}=0.669
$$

The same calculation for alternatives A2 through A10 produces the complete $S_{i}$ Matrix value. From the Fuzzy TOPSIS calculation, the alternative order shown in table 5.

The application not only shows the sorted results but also displays the details of each alternative. Results and detail page displayed in fig. 3 and fig. 4. 
Table 5. Sorted alternative matrix

\begin{tabular}{|l|l|l|c|c|c|}
\hline \multicolumn{1}{|c|}{ Alternative } & \multicolumn{1}{c|}{ C2 } & \multicolumn{1}{c|}{ C4 } & C9 & S $_{\mathbf{i}}$ & Ranking \\
\hline Alt-7 & Cheap & Near & 1 & 1 & 1 \\
\hline Alt-1 & Expensive & Near & 1 & 0.699 & 2 \\
\hline Alt-3 & Moderate & Moderate & 1 & 0.609 & 3 \\
\hline Alt-5 & Expensive & Moderate & 1 & 0.494 & 4 \\
\hline Alt-2 & Expensive & Near & 0 & 0.48 & 5 \\
\hline Alt-10 & Expensive & Near & 0 & 0.48 & 6 \\
\hline Alt-8 & Expensive & Far & 1 & 0.456 & 7 \\
\hline Alt-4 & Moderate & Far & 0 & 0.384 & 8 \\
\hline Alt-6 & Expensive & Far & 0 & 0.313 & 9 \\
\hline Alt-9 & Expensive & Far & 0 & 0.313 & 10 \\
\hline
\end{tabular}

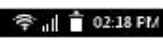

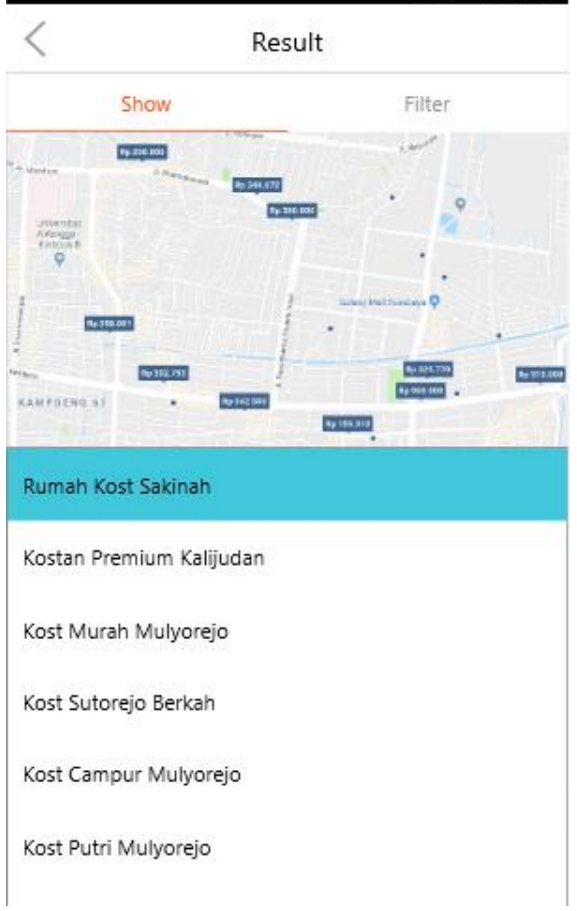

Fig. 4. Result page 


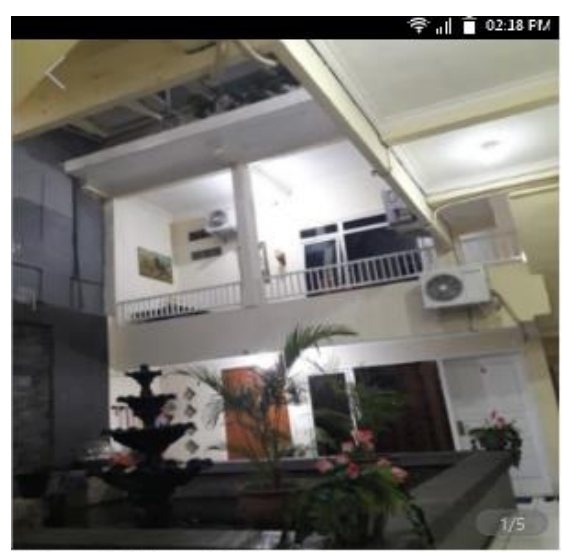

Rumah Kost Sakinah

Jl. Raya Mulyosari No.39, Kalisari, Kec. Mulyorejo, Kota SBY Rp.110K/ Night

Rp.1.500K / Month

A. Max 2 people

No guest above $10 \mathrm{PM}$

$4 \mathrm{TV}$ and Fridge

(\$) Bed

D nurside hathmonm

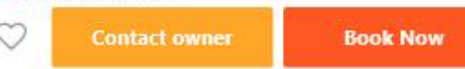

Fig. 5. Boarding house detail page

\subsection{Deployment}

In this stage, the evaluation phase is carried out to find out the user experience and obtain the feedback to be developer evaluation. To evaluate the system, we use User Acceptance Testing based on ISO 9126. User Acceptance Testing is the verification process by users to evaluate system solutions made for users. This process is different from system testing, which ensures the software does not crash and complies with the user's request document, but ensures that the solution in the system will work for the user. In other words, a test that the user accepts a solution in the system.

The system was evaluated by 20 students and five mobile application expertise to evaluate Functionality (F), Usability (U), Content (C), Reliability (R), and Performance of the application $(\mathrm{P})$, as shown in Table 6. Using a 4-point scale, the average weighted mean was computed and interpreted as (1) 3.26-4.0: Excellent; (2) 2.51-3.25: Very Satisfactory; (3) 1.76-2.50: Satisfactory; and (4) 1.00-1.75: Needs Improvement. Usefulness reviewed with a mean of 3.5. It implies that the apps are easy to understand and simple to work. Ease of use additionally assessed with a mean of 3.8. It means that the application is productive to utilize, has an instinctive plan, and easy to explore. The content evaluated with a mean of 3.4 , which can demonstrate that the apps are exact. Reliability quality has a mean of 3.5, which signifies that the respondents exceptionally appraised the nonappearance of disappointment and conformance. Performance has a 
mean of 3.5, which can be verbally-deciphered as palatable. The application has an acceptable introduction before the users. Overall, the application evaluated as 3.54 over which can be verbally-translated as excellent.

Table 6. Evaluation result

\begin{tabular}{|l|c|l|}
\hline \multicolumn{1}{|c|}{ Criteria } & Mean & \multicolumn{1}{c|}{ Verbal Interpretation } \\
\hline $\mathrm{F}$ & 3.5 & Excellent \\
\hline $\mathrm{U}$ & 3.8 & Excellent \\
\hline $\mathrm{C}$ & 3.4 & Excellent \\
\hline $\mathrm{R}$ & 3.5 & Excellent \\
\hline $\mathrm{P}$ & 3.5 & Excellent \\
\hline Grand Mean & 3.54 & Excellent \\
\hline
\end{tabular}

\section{Conclusion and Future Work}

Generally, this paper produces an Android and GIS based system that can help students in choosing a boarding house based on their preferences. Different user preferences in boarding house selection, especially in terms of budget and boarding house facilities, are the main issues of this study. This application uses the fuzzy TOPSIS method to solve boarding house selection problems by identifying criteria and priorities that affect the boarding house selection process and then ranking the results. While GIS gives the visualization of the location and distance.

In this study, 15 criteria can be used by the users in choosing a boarding house, namely: CCTV, Monthly Boarding Prices, Payment term systems, Boarding houses distance to campus, Distance to public facilities, Cleaning facilities, Parking facilities, Electronic facilities, Equipment facilities (bed, desk, and chair), Communal room facilities, Roommate, The environment around the boarding house, The reputation of a boarding house, Clean water service, Electricity service. This variable was obtained from previous studies that had been determined by 100 students.

To test the quality of the software, we use the characteristics of the ISO 9126 standard, namely: functionality, usability, content, reliability, and performance. The testing was conducted by 20 students and five mobile application experience on usability, completeness, performance, and the overall system. The result shows that users consider the features provided in this application to be very good and useful. The users also suggest adding more features such as features related to the boarding house community, ratings, reviews, and reservations so that they can see the best boarding houses based on ratings and communicating with each other.

This study has several limitations. Firstly, the data were obtained only from students in Surabaya. The data from other cities or even from other countries can further confirm the results of this study. Secondly, this study only considers the self-listing boarding house in Surabaya. The data from other resources come from boarding house websites, such as mamikos.com or infokost.id may reveal a better result. Lastly, although our apps were implemented to find the appropriate boarding house based on user preferences, the proposed method can also be implemented for other types of boarding houses 
with other applications that already well known by the public, such as Tripadvisor and Airyroom. This limitation will be a fruitful avenue for future research.

\section{$5 \quad$ References}

[1] N. M. Suki and I. A. Chowdhury, "Students' attitude and satisfaction living in sustainable on-campus hostels," Malaysian J. Bus. Econ., vol. 2, no. 1, pp. 35-47, 2015.

[2] J. Khalid, A. J. Ali, and M. R. Bustami, "Critical factors affecting interna-tional students ' satisfaction of hostel facilities : A case study of Universiti Sains Malaysia," Pros. Konvensyen Kepengetuaan dan Felo Penghuni Kolej Kediam. Univ. Awam Kebangs., no. 2009, pp. 71-79, 2018.

[3] D. R. Anamisa, A. Rachmad, and R. Widiastutik, "Selection system of the boarding house based on fuzzy multi attribute decision making method," J. Theor. Appl. Inf. Technol., vol. 92, no. 1, pp. 52-58, 2016.

[4] P. A. Primanda, E. Santoso, and T. Afirianto, "Pemilihan Kost di Sekitar Universitas Brawijaya menggunakan Metode Analytical Hierarchy Process (AHP) dan Simple Additive Weighting (SAW), J. Pengemb. Teknol. Inf. dan Ilmu Kom-put. Univ. Brawijaya, vol. 2, no. 2548-964X, 2018. https://doi.org/10.33299/jpkop.22.1.1322

[5] M. P. Abella, L. M. Pecdasen, G. G. R. Fajardo, L. G. Pascual, and M. N. Ja-mis, "Board me app: A mobile application for finding boarding houses in universi-ty belt," IEEE Reg. 10 Annu. Int. Conf. Proceedings/TENCON, vol. 2017-Decem, pp. 828-832, 2017. https:// doi.org/10.1109/tencon.2017.8227973

[6] I. M. A. Wirawan and I. W. B. Diarsa, "Mobile-based Recommendation Sys-tem for the Tour Package Using the Hybrid Method," Int. J. Interact. Mob. Tech-nol., vol. 12, no. 8, p. 64, 2018. https://doi.org/10.3991/ijim.v12i8.9483

[7] S. Papadakis, M. Kalogiannakis, E. Sifaki, and N. Vidakis, "Access moodle using smart mobile phones. A case study in a Greek University," in Interactivity, Game Creation, Design, Learning, and Innovation, Springer, 2017, pp. 376-385. https://doi.org/10.1007/9783-319-76908-0_36

[8] S. Papadakis and M. Kalogiannakis, "Mobile educational applications for children: what educators and parents need to know," Int. J. Mob. Learn. Organ., vol. 11, no. 3, pp. 256277, 2017. https://doi.org/10.1504/ijmlo.2017.085338

[9] S. Papadakis, "Evaluating pre-service teachers' acceptance of mobile devic-es with regards to their age and gender: a case study in Greece.," IJMLO, vol. 12, no. 4, pp. 336-352, 2018. https://doi.org/10.1504/ijmlo.2018.10013372

[10] M. Kalogiannakis and S. Papadakis, "Evaluating pre-service kindergarten teachers' intention to adopt and use tablets into teaching practice for natural sci-ences," Int. J. Mob. Learn. Organ., vol. 13, no. 1, pp. 113-127, 2019. https://doi.org/10.1504/ijmlo.2019.1001 $\underline{6617}$

[11] A. Arief, Widyawan, and B. Sunafri Hantono, "Rancang Bangun Sistem Rekomendasi Pariwisata Mobile dengan Menggunakan Metode Collaborative Fil-tering dan Location Based Filtering,” Jnteti, vol. 1, no. 3, 2012. https://doi.org/10.33387/protk.v3i1.38

[12] Y. Yun, D. Hooshyar, J. Jo, and H. Lim, "Developing a hybrid collaborative filtering recommendation system with opinion mining on purchase review," J. Inf. Sci., vol. 44, no. 3, pp. 331-344, 2018. https://doi.org/10.1177/0165551517692955

[13] M. Nilashi, O. Ibrahim, and K. Bagherifard, "A recommender system based on collaborative filtering using ontology and dimensionality reduction techniques," Expert Syst. Appl., vol. 92, pp. 507-520, 2018. https://doi.org/10.1016/j.eswa.2017.09.058 
[14] Y. Zhong, X. Song, B. Yang, C. Jiang, and X. Luo, “An Interpretable Rec-ommendations Approach Based on User Preferences and Knowledge Graph," in International Conference on Swarm Intelligence, 2019, pp. 326-337. https://doi.org/10.1007/978-3-030-26354-6_33

[15] H. Liu, J. He, T. Wang, W. Song, and X. Du, "Combining user preferences and user opinions for accurate recommendation," Electron. Commer. Res. Appl., vol. 12, no. 1, pp. 14-23, 2013. https://doi.org/10.1016/j.elerap.2012.05.002

[16] F. Effendy, Barry Nuqoba, and Taufik, "CULINARY RECOMMENDATION APPLICATION BASED ON USER PREFERENCES USING FUZZY TOPSIS,” IIUM Eng. J., vol. 20, no. 2, pp. 163-175, Dec. 2019. https://doi.org/10.31436/iiumej.v21i1.1023

[17] E. N. Jannah, M. Masrur, and S. Asiyah, "Penerapan Framework Yii dalam Pembangunan Sistem Informasi Asrama Santri Pondok Pesantren sebagai Media Pencarian Asrama Berbasis Web," J. Inf. Syst. Eng. Bus. Intell., vol. 1, no. 2, p. 49, 2015. https://doi.org/10.20473/jisebi.1.2.49-58

[18] M. L. L. Consignado, M. L. Velasco, A. P. Sanvictores, A. Jain, and F. Bala-hadia, "HAYBOL: An Android-Based Apartment Locator Application," Int. J. Comput. Sci. Res., vol. 1, no. 2, pp. 1-9, 2017.

[19] Tiara Ratna Sari, Kartono, and D. Herawati, "Rancang Bangun Sistem Pen-dukung Keputusan Pemilihan Kos Daerah Surabaya Dengan Metode Fuzzy Top-sis Berbasis Mobile," Universitas Airlangga, 2016.

[20] R. S. Pressman, "Software engineering, sevent edition," Am. Mc-Graw Hill, 2010.

[21] P. J. Pradana, P. Setijanti, and D. Septanti, "Boarding House Preferences by Middle Up Class Students in Surabaya," Int. J. Eng. Res. Adv. Technol., vol. 05, no. 02, pp. 38-45, 2019. https://doi.org/10.31695/ijerat.2019.3379

[22] A. Nurdini, "Refleksi Pemenuhan Kebutuhan Hunian Transien di Perkotaan: Kasus Tipologi Lokasi Hunian Sewa Mahasiswa di Kota Bandung," in Temu Ilmiah IPLBI, 2012, no. November, pp. 33-36. https://doi.org/10.32315/ti.6.g029

[23] D. Amole, “Typological Analysis of Students' Residences," Archnet-IJAR - Int. J. Archit. Res., vol. 1, no. 3, pp. 76-87, 2007.

[24] L. Science and P. Company, "Student's Housing Preferences in Southwest-ern in Nigeria," J. Archit. Plann. Res., vol. 28, no. 1, pp. 44-57, 2011.

[25] S. HAJAR, M. SUSILAWATI, and D. P. E. NILAKUSMAWATI, "Faktor-Faktor Yang Memengaruhi Keputusan Mahasiswa Dalam Memilih Rumah Kost,” E-Jurnal Mat., vol. 1, no. 1, pp. 25-31, 2012. https://doi.org/10.30997/jtm.v3i2.1868

[26] D. S. Madyaratri, P. Hardati, and M. Arifien, "Karakteristik Buruh Industri Dan Preferensi Terhadap Pemilihan Rumah Kost Di Kelurahan Ngempon Keca-matan Bergas Kabupaten Semarang Tahun 2016," Geo Image, vol. 6, no. 1, pp. 1-10, 2017.

[27] H. Y. Wu, G. H. Tzeng, and Y. H. Chen, "A fuzzy MCDM approach for evaluating banking performance based on Balanced Scorecard," Expert Syst. Appl., vol. 36, no. 6, pp. 1013510147, 2009. https://doi.org/10.1016/j.eswa.2009.01.005

[28] S. Opricovic and G. H. Tzeng, "Compromise solution by MCDM methods: A comparative analysis of VIKOR and TOPSIS,” Eur. J. Oper. Res., vol. 156, no. 2, pp. 445-455, 2004. https://doi.org/10.1016/s0377-2217(03)00020-1

[29] J. F. Andry, J. S. Suroso, and D. Y. Bernanda, "Improving quality of SMEs information system solution with ISO 9126,” J. Theor. Appl. Inf. Technol., vol. 96, no. 14, pp. 46104620, 2018.

[30] H. Sutopo, R. S. Samosir, and J. Gatc, "Mobile multimedia evaluation: De-velopment of stop drugs tutorial," Int. J. Interact. Mob. Technol., vol. 13, no. 5, pp. 124-136, 2019 https://doi.org/10.3991/ijim.v13i05.9436 


\section{Authors}

Faried Effendy is a lecturer at Information System Study Program, Universitas Airlangga, Indonesia. He is a member of the International Association of Online Engineering (IAOE), Asosiasi Perguruan Tinggi Ilmu Komputer (APTIKOM), and Indonesian Mathematical Society (IndoMS). His research interest includes Information System Engineering and Business Intelligence.

Kartono is a senior lecturer, the secretary of the Professional Certification Body (LSP) of Universitas Airlangga, Indonesia, and former director of Politeknik Surabaya, Indonesia. Currently, he still serves as the director of the Indochito group International. His research interest includes Decision Support System and Algorithm.

Dyah Herawati is a senior lecturer at Universitas Airlangga and P.hD candidate of Industrial Engineering. She is a member of Asosiasi Perguruan Tinggi Ilmu Komputer (APTIKOM). Her research interest includes Decision Support System and Supply Chains Management.

Article submitted 2019-08-25. Resubmitted 2020-03-24. Final acceptance 2020-03-25. Final version published as submitted by the authors. 